\title{
How Glyphosate May Affect Transgenic Soybean in Different SoIl ANd Phosphorus Levels ${ }^{1}$
}

\author{
Influência do Glyphosate na Soja Transgênica em Diferentes Solos e Níveis de Fósforo
}

\author{
CASONATTO, M.S. ${ }^{2}$, ARANTES, S.A.C.M., RIEGER, E.A. ${ }^{2}$, and ANDRADE, E.A. ${ }^{2}$
}

\begin{abstract}
The technology that employs genetic modifications brought a significant increase in the utilization of glyphosate. Transgenic soybean has been suffering injury, even though it possesses a resistance mechanism to glyphosate. Currently, there are only a few studies on the dynamics of glyphosate in transgenic soybean planted in soils with different textures interacting with phosphorus concentrations. This study focused on assessing the effects of glyphosate in transgenic soybean plants on different types of soil and at different phosphorus levels. The experimental design was completely randomized, in factorial design: $2 \times 6 \times 3$, that being 2 soil types, 6 doses of glyphosate and 3 levels of phosphorus, and four replications. Plants were cultivated for thirty days in pots with two types of soil, one being clayey (RedYellow Latosol) and the other sandy (Quartzarenic Neosol). They received one, two, and three times the maintenance dose of fertilization of phosphorus, corresponding to: 170, 250 and $330 \mathrm{~kg}$ of $\mathrm{P}_{2} \mathrm{O}_{5}$ ha $^{-1}$ to QN, and 380, 460 and $540 \mathrm{~kg} \mathrm{P}_{2} \mathrm{O}_{5}$ ha $^{-1}$ to RYL, respectively. Glyphosate was applied at six different doses: 0, 1,200, 2,400, 12,000,60,000 and 120,000 $\mathrm{g} \mathrm{ha}^{-1}$ of active ingredient. Plant height, $a$ and $b$ chlorophyll, and shoot were lower for the plants that received lower doses of glyphosate, regardless of the type of soil. Greater availability of phosphorus and lower amount of glyphosate used in Quartzarenic Neosol soil provided for less phytointoxication symptoms in transgenic soybean.
\end{abstract}

Keywords: phosphorus fertilization, herbicide, selectivity, genetic modifications.

RESUMO - A tecnologia que emprega organismos geneticamente modificados trouxe aumento considerável na utilização do glyphosate; entretanto, a soja transgênica (RR), embora possuia mecanismo de resistência, tem sofrido injúrias. Atualmente, são poucos os estudos envolvendo a dinâmica desse herbicida na soja transgênica cultivada em solos com diferentes texturas e concentrações de fósforo. O objetivo deste estudo foi avaliar os efeitos do glifosato na soja transgênica em diferentes solos e niveis de fósforo. O delineamento experimental foi o inteiramente casualizado, em esquema fatorial: $2 \times 6 \times 3$, correspondendo a dois solos, seis doses do glyphosate e três níveis de fósforo, com quatro repetições. Cultivou-se, por 30 dias, uma planta de soja em vasos com dois solos: um argiloso LVA (Latossolo Vermelho-Amarelo) e outro arenoso RQ (Neossolo Quartzarênico), que receberam uma, duas e três vezes a dose recomendada de manutenção de fósforo, correspondendo a 170, 250 e $330 \mathrm{~kg}$ de $\mathrm{P}_{2} \mathrm{O}_{5} \mathrm{ha}^{-1}$ para o RQ e 380, 460 e $540 \mathrm{~kg}$ de $\mathrm{P}_{2} \mathrm{O}_{5}$ ha-1 para o LVA, respectivamente; o glyphosate foi aplicado em seis diferentes doses: 0, 1.200, 2.400, 12.000, 60.000 e $120.000 \mathrm{~g} \mathrm{ha}^{-1}$ de ingrediente ativo. A altura de plantas, clorofilas a e b e biomassas úmida e seca da parte aérea foram menores nas plantas que receberam as maiores doses de glyphosate, independentemente do solo. Maior disponibilidade de fósforo no Neossolo Quartzarênico, em menores doses de glyphosate, proporcionou menores sintomas de fitointoxicação nas plantas de soja RR.

Palavras-chave: adubação fosfatada, herbicida, seletividade, transgenia.

Recebido para publicação em 26.2.2014 e aprovado em 22.7.2014.

Universidade Federal de Mato Grosso, Sinop-MT, Brazil, <marilzadasilva2901@gmail.com>.

Planta Daninha, Viçosa-MG, v. 32, n. 4, p. 843-850, 2014 


\section{INTRODUCTION}

The state of Mato Grosso in Brazil stood out among the largest local producers of soybean: in the $2011 / 2012$ harvest, approximately $70 \%$ of the area was planted with transgenic soybean (Roundup Ready - RR®) resistant to glyphosate (IMEA, 2012).

According to Yamada \& Castro (2007), the mechanism of action of glyphosate, able to effectively control weeds, is based on the interruption of the shikimic acid. It inhibits 5-enolpyruvylshikimate-3-phosphate synthase (EPSP) activity, responsible for the production of aromatic amino acids such as phenylalanine, tyrosine and tryptophan, and hence, associated with: synthesis of auxin and other phytohormones, chlorophyll synthesis, phytoalexin and lignin synthesis, protein synthesis, photosynthesis, respiration, perspiration and permeability of membranes.

According to Serra et al. (2011), transgenic technology has brought considerable increase in the use of glyphosate, especially in postemergence, and it is applied three to four times during the cycle of soybeans. These successive applications of a single product have a negative impact on plant nutrition. It is noteworthy that in transgenic soybeans, although having a resistance mechanism, the literature reports the possible negative effects of glyphosate on the early development of plants (Santos et al., 2007).

Typical symptoms observed after the application of glyphosate is known as yellow flashing, which is the yellowing of the upper leaves; chlorosis in RR soybeans can be associated with the immobilization of divalent cations such as Fe and Mn (Bott et al., 2008). One of possibility that could explain the lower availability of these nutrients in plant tissues is the fact that glyphosate, as a phosphonic acid, has chelating properties of metal cations, such as divalent and trivalent cations (Zobiole et al., 2010). For Reddy et al. (2004), the chlorotic symptom in RR soybean is associated with the accumulation of AMPA (aminomethylphosphonic acid), parent compound of degradation and first phytotoxic metabolite of glyphosate, which is one of the elements responsible for decreased dry biomass of shoot and root and chlorophyll content.
Santos et al. (2007) argue that the injury caused by glyphosate in transgenic soybeans may be related to excessive increased of dose, to the application of other glyphosate formulations that are not recommended for this culture, or to the effect of other natural or synthetic chemicals, such as surfactants or allelochemicals, that may even reduce its productivity.

By studying the prevention of injuries caused by glyphosate on RR soybean when using amino acids, Zobiole et al. (2011) have concluded that, decreased photosynthetic rate and chlorophyll production caused by glyphosate have lowered plant height and production of dry biomass of shoot, root and, consequently, total biomass.

Phosphorus is a nutrient used on farms throughout Brazil, and its relation to the effects of glyfosate in transgenic soybean is still unknown, since these two molecules interrelated in the soil.

Metabolites and physiological effects caused by glyphosate - mainly the reduction in total biomass - can be offset by phosphorus. Taiz \& Zeiger (2013) state that this macronutrient is an integral component of important compounds of plant cell, and the main symptom of its deficiency in the plant is reduced growth. According to Novais et al. (2007), phosphorus plays an important role in photosynthesis, respiration, energy storage and transfer, cell division and growth, and other processes occurring in the plant.

This paper's hypothesis is that the transgenic soybean, when submitted to the application of glyphosate, presents better development when it has proper supply of phosphorus; sandy texture soils tend to favor the better availability of phosphorus.

Considering such conditions, this paper aimed to assess the effects of glyphosate on transgenic soybean in soils with different textures and with different levels of phosphorus.

\section{MATERIALS AND METHODS}

Samples of both soils were collected in July 2012, which were classified according to the Brazilian Agricultural Research Corporation 
(Embrapa, in the Portuguese acronym) (2006) as Red-Yellow Latosol (RYL) and Quartzarenic Neosol (QN), at 0-20 cm depth. They were submitted to chemical analysis, in which the following were determined: levels of cation of the exchangeable complex (calcium, magnesium and potassium), water $\mathrm{pH}$, available phosphorus, organic matter; and physical analysis - where clay, silt, and sand were assessed, in accordance with Embrapa (1997). Results are shown in Tables 1 and 2.

The experiment was conducted according to a completely randomized design (CRD), in factorial $2 \times 6 \times 3$, corresponding to two soils, six doses of glyphosate, and three levels of phosphorus, with four replications for the variables: plant height, chlorophyll and phytotoxicity, and wet and dry shoot biomass.

After the chemical and physical characterization of soil was determined, soil adjustment, according to Raij (1981), and incubation with limestone filler (PRNT 99\%) were conducted for 90 days. Next, they were placed in $7 \mathrm{~kg}$ vessels, and received fertilizers according to the chemical analysis and need of soybean culture; as for phosphorus, the recommended maintenance dose (MD) was applied once, twice and three times, corresponding to: 170,250 and $330 \mathrm{~kg}$ of $\mathrm{P}_{2} \mathrm{O}_{5}$ ha $^{-1}$ for QN and 380,460 and $540 \mathrm{~kg}$ of $\mathrm{P}_{2} \mathrm{O}_{5}$ ha $^{-1}$ for RYL, respectively. On the same day of fertilization, two seeds of transgenic TMG 132 RR soybean were sown, with subsequent thinning seven days after sowing (DAS), leaving only one seedling.
The application of Roundup Original $\AA$ glyphosate on transgenic soybean occurred at $30 \mathrm{DAS}$, on the following dosages: 1,200, $2,400,12,000,60,000$ and 120,000 g i.a. $h^{-1}$ (active ingredient) and a condition with no application (control). In order to do so, a carbon dioxide (CO2) pressurized backpack sprayer with a 110015 spray range tip was used. The service pressure used was $2 \mathrm{kgf}^{-2}$, providing spray volume of $150 \mathrm{~L} \mathrm{ha}^{-1}$. This application was made in the morning, between 7 and $10 \mathrm{am}$, when the average room temperature was $27^{\circ} \mathrm{C}$ and relative humidity around $80 \%$, with no wind.

To determine the effects of glyphosate on the development of soybean plants, at 30, 33 and 40 days after sowing (DAS), the following parameters were assessed: plant height $(\mathrm{cm})$, phytotoxicity, and $a$ and $b$ content of chlorophyll. In addition, at $40 \mathrm{DAS}$, shoot dry and wet biomasses (g) were also assessed.

Plant height was measured in the stem: from soil to the insertion of completely open penultimate trefoil; on the median leaf of this same trefoil, chlorophyll content was measured, using a Falker ${ }^{\circledR}$ meter (ClorofiLog 1.11). Assessment of phytotoxicity was carried out by four people to obtain an average score; thus, a score grid was used to establish the criterion of percentage of leaf area with symptoms, as follows: grade 0 (no symptoms), 1 (1-20\%), 2 (21-40\%), 3 (41 to 60\%), 4 (61 to $80 \%)$ and 5 (81 to $100 \%)$ following the methodology used by Martins et al. (2004) and Reis et al. (2010).

Table 1 - Chemical properties of Red-Yellow Latosol (RYL) and Quartzarenic Neosol (QN)

\begin{tabular}{|c|c|c|c|c|c|c|c|c|}
\hline \multirow{2}{*}{ Soil } & $\mathrm{pH}$ & $\mathrm{P}$ & $\mathrm{K}$ & $\mathrm{Ca}$ & $\mathrm{Mg}$ & $\mathrm{Al}$ & $\mathrm{H}$ & \multirow{2}{*}{$\frac{\text { M.O }}{\left(\mathrm{g} \mathrm{dm}^{-3}\right)}$} \\
\hline & $\left(\mathrm{H}_{2} \mathrm{O}\right)$ & \multicolumn{2}{|c|}{$\left(\mathrm{mg} \mathrm{dm}^{-3}\right)$} & \multicolumn{4}{|c|}{$\left(\mathrm{cmol}_{\mathrm{c}} \mathrm{dm}^{-3}\right)$} & \\
\hline RYL & 5.22 & 1.35 & 37 & 1.55 & 0.67 & 0.10 & 4.93 & 39.97 \\
\hline QN & 4.35 & 0.51 & 11 & 0.06 & 0.05 & 0.95 & 3.75 & 18.59 \\
\hline
\end{tabular}

Table 2 - Physical properties of Red-Yellow Latosol (RYL) and Quartzarenic Neosol (QN)

\begin{tabular}{|l|c|c|c|c|c|}
\hline \multirow{2}{*}{ Soil } & Sand & Silt & Clay & \multirow{2}{*}{ Textural class } & Density \\
\cline { 2 - 4 } & \multicolumn{3}{|c|}{$\left(\mathrm{g} \mathrm{kg}^{-1}\right)$} & & $\left(\mathrm{g} \mathrm{cm}^{-3}\right)$ \\
\hline RYL & 374 & 146 & 480 & Clayey & 0.99 \\
\hline QN & 800 & 086 & 114 & Sandy & 1.39 \\
\hline
\end{tabular}


At 40 DAS, all plants were sectioned at the stem, separating the shoot from the root. The shoot was weighed on a precision scale and then oven-dried at $65{ }^{\circ} \mathrm{C}$ forced ventilation until complete drying.

The SISVAR program (Ferreira, 2003) was used to submit the results to analysis of variance; whenever it showed significant difference among treatments, the Tukey test at $5 \%$ probability was performed to compare means, or regression analysis, for quantitative data. The phytotoxicity variable underwent a transformation, where the transformation $(\mathrm{x}+1) 1 / 2$ was used, for having more effectively stabilized the variance.

\section{RESULTS AND DISCUSSION}

After the application of glyphosate at 30 DAS (days after sowing), generally no significant differences were found in the variables analyzed. At 33 DAS, the same occurred to the variables plant height and $a$ and $b$ chlorophyll.

When analyzing transgenic soybean plant phytotoxicity, it was possible to observe that symptoms increased with increasing dosages of glyphosate (Figure 1). This result can be explained by the mechanism of action of glyphosate, which interferes with the shikimic acid pathway, causing many physiological effects on plants, such as the typical symptoms of intoxication, which, according to Karam \& Oliveira (2007), are the hindering of growth, the yellowing of meristems and young leaves, reddish or streaked leaves, with subsequent necrosis and plant death. Santos et al. (2007) have also found phytointoxication in transgenic soybean plants when three formulations of glyphosate were applied.

At 40 DAS, transgenic soybean plants growth decreased (Figure 2), and $a$ and $b$ chlorophyll decreased with increasing rates of glyphosate (Figure 3). As previously mentioned, by affecting the shikimic acid, glyphosate inhibits 5-enolpyruvylshikimate-3-phosphate synthase (EPSP), which is in charge of the production of aromatic amino acids, which, in turn, affect the synthesis of secondary metabolites, influencing the synthesis of auxin indole acetic acid (IAA), which is a plant growth promoter (Yamada \& Castro, 2007), which

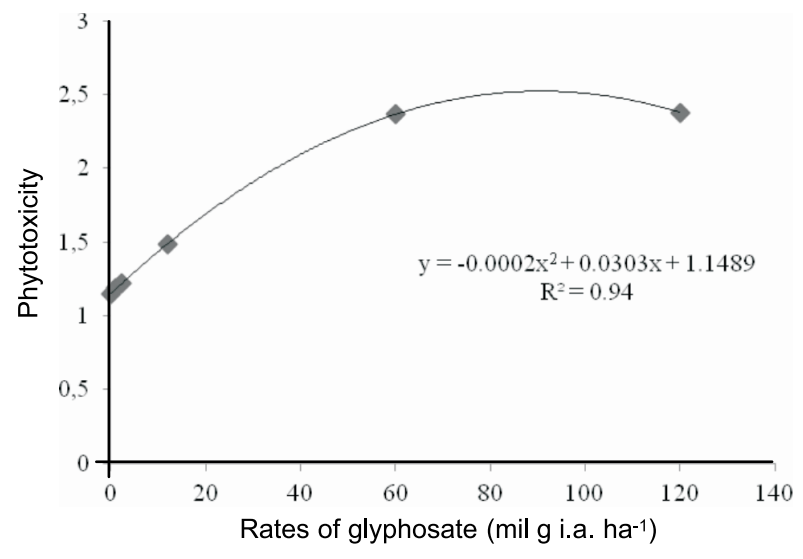

Figure 1 - Phytotoxicity of RR soybean plants at 33 DAS (days after sowing), in relation to rates of glyphosate.

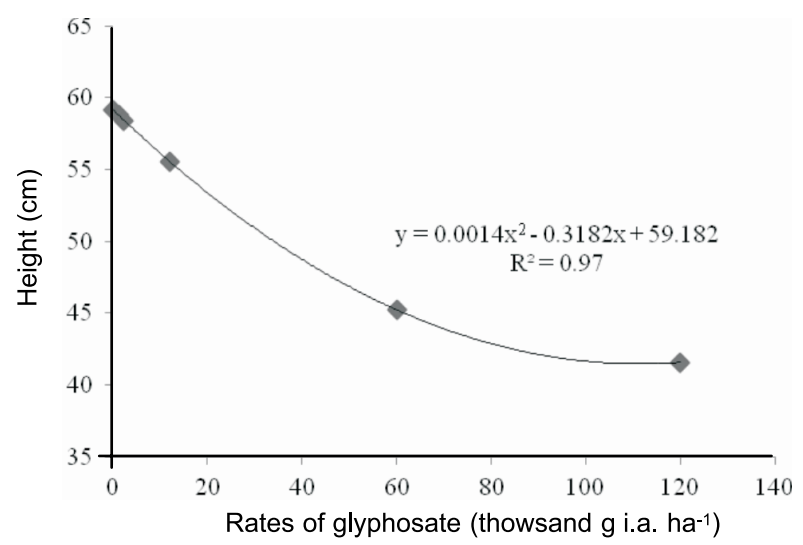

Figure 2 - Height of RR soybean plants at 40 DAS (days after sowing), in relation to rates of glyphosate.

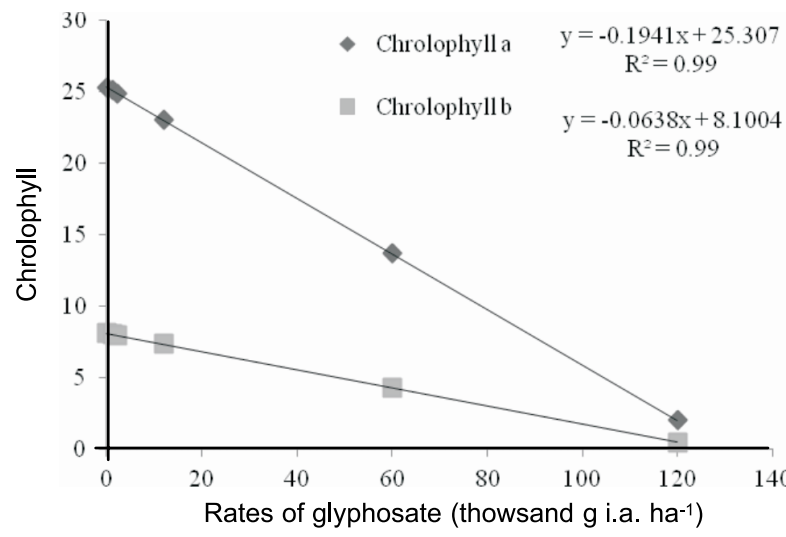

Figure 3 - A and b chlorophyll content of RR soybean plants at 40 DAS (days after sowing), in relation to rates of glyphosate. 
occurs, as stated by Taiz \& Zeiger (2013), according to the hypothesis of acid growth, by the extrusion of protons induced by this hormone, thus increasing cellular extension (elongation).

Results for $a$ and $b$ chlorophyll are probably due to the decrease in nutrient absorption. Zobiole et al. (2010) report that this chlorosis can be associated with the immobilization of divalent cations, such as $\mathrm{Fe}$ and $\mathrm{Mn}$, since glyphosate, as a phosphonic acid, (Franz et al. 1997) has chelating properties of metal cations (Kabachnik et al. 1974).

Regarding the importance of chlorophyll, Taiz \& Zeiger (2013) argue that it is essential to capture solar energy and ensure the growth and development of plants.

Even though the soybean plants included in this study are transgenic cultivars, results for chlorophyll have shown that glyphosate interferes with the metabolism of the plant. These results agree with the literature in that some GM soybean cultivars are visually injured by glyphosate (Zablotowicz \& Reddy, 2007). This may be due to the fact that transgenic soybean, even being glyphosate resistant, still has the original genetic information of the species, thereby being sensitive to its effects. For Reddy et al. (2000), glyphosate affects transgenic soybean, since it can be absorbed and metabolized by plants, possibly altering secondary metabolism, since the endogenous EPSP enzyme remains unchanged.

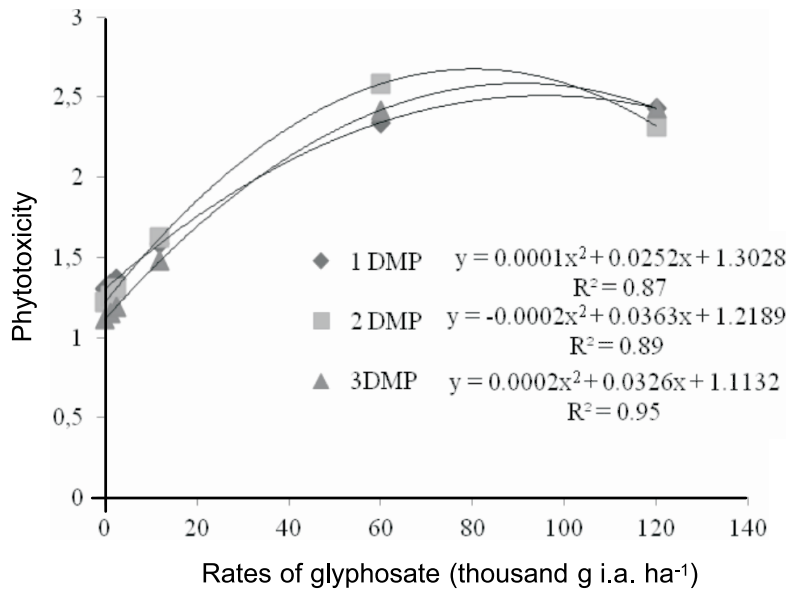

Figure 4 - Phytotoxicity of RR soybean plants at 40 DAS (days after sowing), in relation to rates of glyphosate and phosphorus levels in Quartzarenic Neosol (QN).
When analyzing the phytotoxicity variable, soil, dosage of glyphosate applied, and phosphorus levels were noted to interact. In general, for both soils (Figures 4 and 5), these symptoms increased with increasing doses of glyphosate on transgenic soybean plants.

According to Table 3, on $\mathrm{QN}$, phytotoxic symptoms decreased with increasing phosphorus levels, with significance at the following glyphosate rates: 1,200, 2,400 and $12,000 \mathrm{~g}$ i.a. ha-1 . Maximum level of phosphorus (3 DMP) and within these dosages, phytotoxicity was greater in the RYL. Such finding shows that the highest level of phosphorus in the soil - along with the physical and chemical features of QN, which favored greater availability - may have provided greater tolerance of soybean plants to this herbicide, considering their better development. Novais et al. (2007) explain that sandy soils have lower phosphorus adsorption capacity: for an equal value of phosphate fertilizer amount, higher values of phosphorus in solution are found, therefore, available to plants, compared with clayey soils.

Results were not significant for the remaining doses of glyphosate. Possibly, injuries were much larger at such rates, excessively compromising the development of transgenic soybean plants.

Shoot wet and dry biomass weight of transgenic soybean plants was lower in higher rates of glyphosate applied, regardless of $\mathrm{P}$ rates (Figure 6).

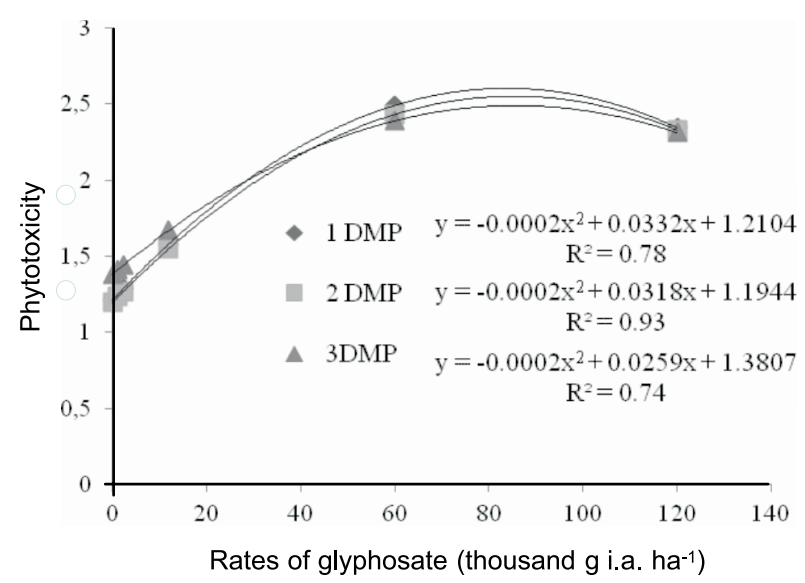

Figure 5 - Phytotoxicity of RR soybean plants at 40 DAS (days after sowing), in relation to rates of glyphosate and phosphorus levels in Red-Yellow Latosol (RYL).

Planta Daninha, Viçosa-MG, v. 32, n. 4, p. 843-850, 2014 
Table 3 - Phytotoxicity of RR soybean plants at 40 DAS (days after sowing), as a function of the maintenance levels of phosphorus (DM), rates of glyphosate, and soils (Red-Yellow Latosol - RYL and Quartzarenic Neosol - QN)

\begin{tabular}{|c|c|c|c|c|c|c|}
\hline \multicolumn{7}{|c|}{ Phytotoxicity } \\
\hline \multirow{2}{*}{$\mathrm{P}$} & \multicolumn{2}{|c|}{ Dose 0 g i.a. ha ${ }^{-1}$} & \multicolumn{2}{|c|}{ Dose 1200 g i.a. ha ${ }^{-1}$} & \multicolumn{2}{|c|}{ Dose 2400 g i.a. ha ${ }^{-1}$} \\
\hline & QN & RYL & QN & RYL & QN & RYL \\
\hline $1 \mathrm{DM}$ & $1.00 \mathrm{aA}$ & $1.00 \mathrm{aA}$ & $1.31 \mathrm{aA}$ & $1.10 \mathrm{aA}$ & $1.49 \mathrm{aA}$ & $1.21 \mathrm{bB}$ \\
\hline $2 \mathrm{DM}$ & $1.00 \mathrm{aA}$ & $1.00 \mathrm{aA}$ & $1.21 \mathrm{aA}$ & $1.21 \mathrm{aA}$ & $1.31 \mathrm{aA}$ & $1.31 \mathrm{bA}$ \\
\hline $3 \mathrm{DM}$ & $1.00 \mathrm{aA}$ & $1.00 \mathrm{aA}$ & $1.00 \mathrm{bB}$ & $1.31 \mathrm{aA}$ & $1.31 \mathrm{aA}$ & $1.65 \mathrm{aA}$ \\
\hline \multirow{2}{*}{$P$} & \multicolumn{2}{|c|}{ Dose $12000 \mathrm{~g}$ i.a. ha ${ }^{-1}$} & \multicolumn{2}{|c|}{ Dose $60000 \mathrm{~g}$ i.a. ha ${ }^{-1}$} & \multicolumn{2}{|c|}{ Dose 120000 g i.a. ha ${ }^{-1}$} \\
\hline & QN & RYL & QN & RYL & QN & RYL \\
\hline $1 \mathrm{DM}$ & $1.86 \mathrm{abB}$ & $2.17 \mathrm{aA}$ & $2.23 \mathrm{aA}$ & $2.28 \mathrm{aA}$ & $2.44 \mathrm{aA}$ & $2.39 \mathrm{aA}$ \\
\hline $2 \mathrm{DM}$ & $1.99 \mathrm{aA}$ & $1.79 \mathrm{bA}$ & $2.44 \mathrm{aA}$ & $2.33 \mathrm{aA}$ & $2.34 \mathrm{aA}$ & $2.34 \mathrm{aA}$ \\
\hline $3 \mathrm{DM}$ & $1.68 \mathrm{bB}$ & $2.05 \mathrm{aA}$ & $2.34 \mathrm{aA}$ & $2.23 \mathrm{aA}$ & $2.44 \mathrm{aA}$ & $2.34 \mathrm{aA}$ \\
\hline
\end{tabular}

${ }^{1 /}$ Lowercase compare the means in the column and capital letters compare the means in the line. Data followed by the same letter do not differ by Tukey test at $5 \%$.

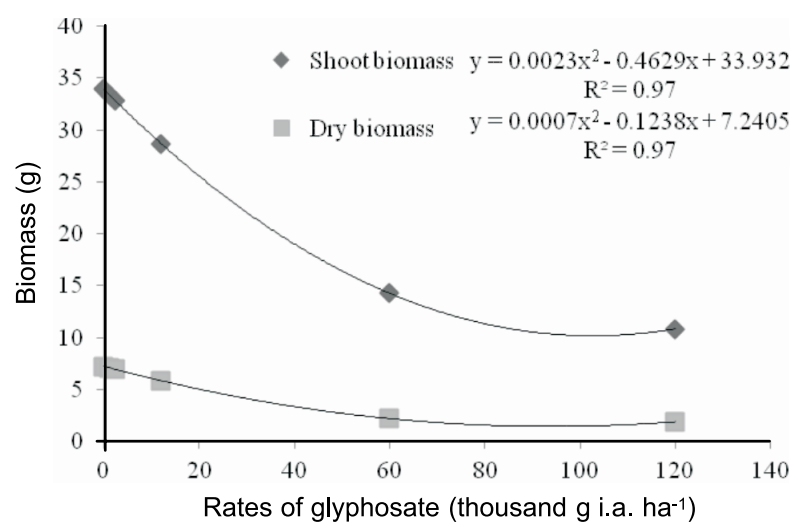

Figure 6 - Shoot wet and dry biomass of RR soybean plants at 40 DAS (days after sowing), in relation to rates of glyphosate.

According to Bott et al. (2008), glyphosate applied to RR soybean reduces biomass and elongation of roots. Thus, such reduction of root can limit the absorption of nutrients in plants treated with glyphosate, hindering their growth and development, reflecting on the wet and dry biomass of shoots, as shown in this present work.

Wet and dry biomass were greater for RYL compared with QN, in a 2 DMP condition (Figures 7A and 8A). These findings corroborate with those found for plant height, where in glyphosate affects the synthesis of tryptophan amino acid, a precursor of auxin, a hormone responsible for cell elongation. According to
Taiz \& Zeiger (2013), dry biomass corresponds to the carbon fixed via photosynthesis, which occurs in two stages: the photochemical stage, involving $\mathrm{a}$ and $\mathrm{b}$ chlorophyll, and the biochemical stage, with the participation of amino acids and enzymes. Thus, the reduction of biomass caused by glyphosate is directly related to smaller cell size and reduced photosynthesis.

Serra et al. (2011) have found that glyphosate has caused a reduction in the production of shoot, root, and total dry biomass in transgenic soybeans, and this fact may be explained by possible reduction of photosynthesis, when glyphosate is applied.

For QN, among phosphorus rates, shoot wet and dry biomass of soybean plants were higher in 3 DMP (Figures 7B and 8B). For RYL, biomass were higher in $2 \mathrm{DMP}$, and statistically equal to 3 DMP. Thus, both for QN and for RYL, shoot wet and dry biomasses were lower in the condition of lower availability of phosphorus in soil. According to Taiz \& Zeiger (2013), phosphorus is an integral component of important compounds of plant cells, including phosphate sugars, which mediate respiration and photosynthesis, membrane phospholipids, and nucleotides used in energy metabolism, such as ATP.

It was observed that, when plants are more well nourished, their growth and development is better, and they are more resistant to injury caused by glyphosate. 
Table 4 - ANOVA at 40 DAS (days after sowing)

\begin{tabular}{|l|c|c|c|c|c|c|c|}
\hline \multirow{2}{*}{ FV } & \multirow{2}{*}{ GL } & \multicolumn{9}{c|}{ Q M } \\
\cline { 3 - 8 } & & Height & Phytotoxicity & Chlorophyll a & Chrolophyll b & Wet biomass & Dry biomass \\
\hline Soil & 1 & $588.06^{*}$ & 0.06 & $227.00^{* *}$ & $54.39^{* *}$ & $955.84^{* *}$ & $13.81^{* *}$ \\
\hline Phosphorus & 2 & 51.67 & 0.05 & 9.46 & 1.04 & $200.1 *$ & 5.81 \\
\hline Dose & 5 & $1467.62^{* *}$ & $99.77^{* *}$ & $2142.66^{* *}$ & $231.44^{* *}$ & $2667.19^{* *}$ & $151.55^{* *}$ \\
\hline Soil x phosphorus & 2 & 201.64 & $0.89^{*}$ & 11.22 & 2.53 & $231.36^{*}$ & $9.99^{* *}$ \\
\hline Soil x dose & 5 & 45.38 & 0.56 & 73.95 & 6.76 & 74.59 & 2.27 \\
\hline Phosphorus x dose & 10 & 92.69 & 0.47 & 41.32 & 5.14 & 67.85 & 2.79 \\
\hline Soil x phos. x dose & 10 & 23.71 & $0.92^{* *}$ & 5.25 & 0.67 & 51.39 & 1.70 \\
\hline error & 108 & 72.45 & 0.28 & 36.87 & 4.37 & 48.50 & 1.92 \\
\hline
\end{tabular}

* Significant at $5 \%$. * Significant at $1 \%$.
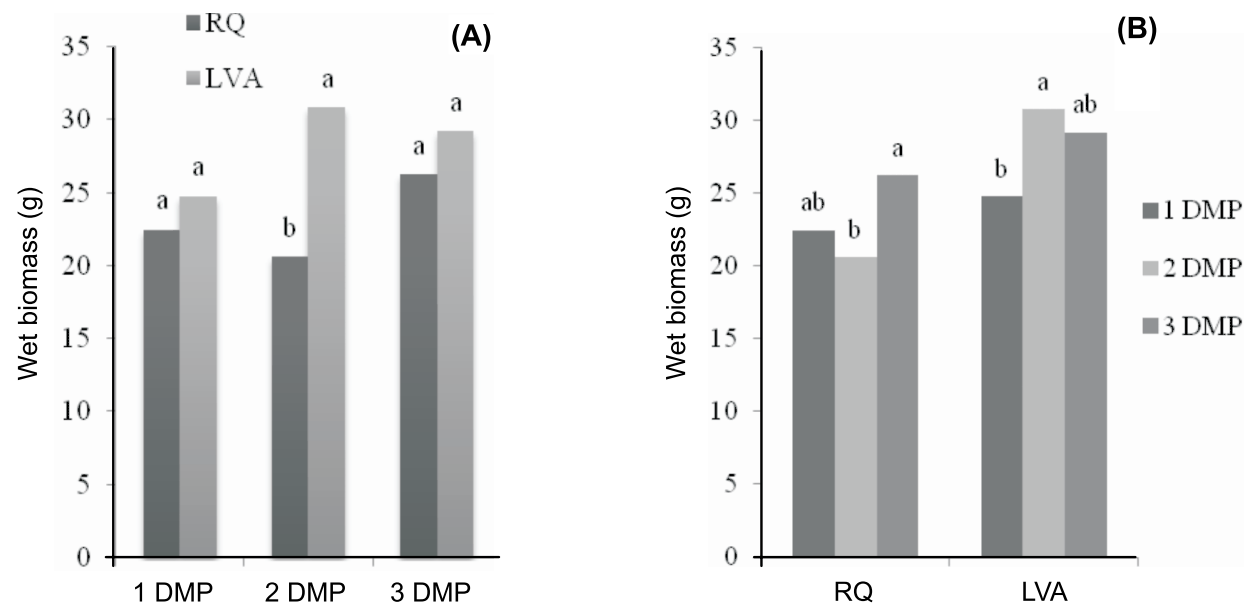

Data followed by the same letter do not differ by Tukey test at $5 \%$.

Figure 7 - Shoot wet biomass of RR soybean plants at 40 DAS (days after sowing) in relation to soils (Red-Yellow Latosol - RYL and Quartzarenic Neosol - QN) and levels of phosphorus.
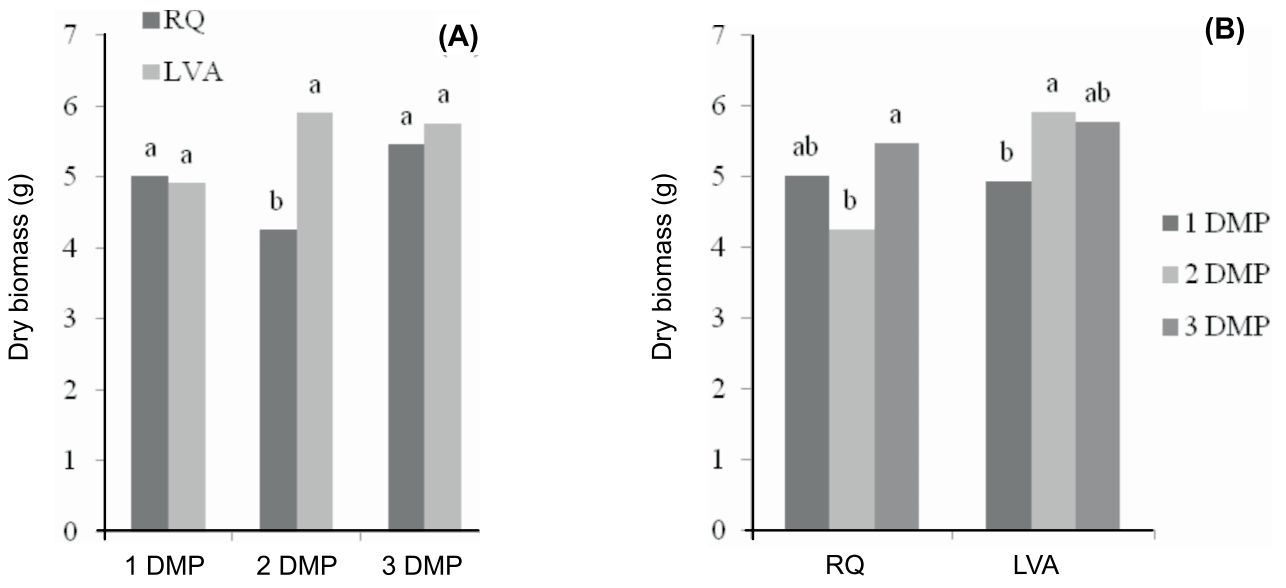

Data followed by the same letter do not differ by Tukey test at $5 \%$.

Figure 8 - Shoot dry biomass of RR soybean plants at 40 DAS (days after sowing) in relation to soils (Red-Yellow Latosol - RYL and Quartzarenic Neosol - QN) and levels of phosphorus. 
According to the results, it can be concluded that under the assessed conditions, plant height, $\mathrm{a}$ and $\mathrm{b}$ chlorophyll, and shoot wet and dry weight were lower for plants receiving the highest rates of glyphosate, regardless of the type of soil. Greater availability of phosphorus in QN, at lower rates of glyphosate, provided for less phytointoxication symptoms in transgenic soybean plants.

\section{LITERATURE CITED}

BOTT, S. et al. Glyphosate-induced impairment of plant growth and micronutrient status in glyphosate-resistant soybean (Glycine max L.). Plant Soil, v. 312, n. 1, p. 185-194, 2008.

\section{EMPRESA BRASILEIRA DE PESQUISA}

AGROPECUÁRIA - EMBRAPA. Centro Nacional de Pesquisa de Solos. Manual de métodos de análise de solo. 2.ed. Rio de Janeiro, 1997. 212 p.

\section{EMPRESA BRASILEIRA DE PESQUISA}

AGROPECUÁRIA - EMBRAPA. Centro Nacional de Pesquisa de Solos. Sistema brasileiro de classificação de solos. 2.ed. Rio de Janeiro, 2006. 306 p.

FERREIRA, D. F. SISVAR. Lavras, Universidade Federal de Lavras, 2003.

FRANZ, J. E.; MAO, M. K.; SIKORSKI, J. A. Glyphosate: a unique global herbicide. Washington: American Chemical Society, 1997. (Monograph, 189).

INSTITUTO MATO-GROSSENSE DE ECONOMIA AGROPECUÁRIA - IMEA Disponível em: <http:// www.imea.com.br/>. Accessed on: April 24th, 2012.

KABACHNIK, M. I. Organophosphorus complexones. Russian Chem. Rev., v. 43, n. 9, p. 733-744, 1974.

KARAM, D.; OLIVEIRA, M. F. Seletividade de herbicidas na cultura do milho. Sete Lagoas: Embrapa Milho e Sorgo, 2007.8 p. (Circular Técnica, 98).

MARTINS, M. C. et al. Escala Diagramática para a quantificação do complexo de doenças foliares de final de ciclo em soja. Fitopatol. Bras., v. 29, n. 2, p. 119-184, 2004.
NOVAIS, R. F. et al. Fertilidade do solo. Viçosa, MG: Sociedade Brasileira de Ciência do Solo, 2007. 1017 p.

RAIJ, B. van. Avaliação da fertilidade do solo. Piracicaba: Associação Brasileira para Pesquisa da Potassa e do Fosfato, 1981. $142 \mathrm{p}$.

REDDY, K. N.; HOAGLAND, R. E.; ZABLOTOWICZ, R. M. Effect of glyphosate on growth, chlorophyll content and nodulation in glyphosate-resistant soybeans (Glycine max varieties). J. New Seeds, v. 2, n. 1, p. 37-52, 2000.

REDDY, K. N.; RIMANDO, A. M.; DUKE, S. K. Aminomethylphosphonic acid, a metabolite of glyphosate, causes injury in glyphosate-treated, glyphosate-resistant soybean. J. Agric. Food Chem., v. 52, n. 16, p. 5139-5143, 2004.

REIS, T. C. et al. Efeitos de fitotoxidade na soja RR tratada com formulações e dosagens de Glifosato. R. Biol. Ci. Terra, v. 10 , n. 1 , p. $34-43,2010$.

SANTOS, J. B. et al. Avaliação de formulações de glyphosate sobre soja roundup ready Planta Daninha, v. 25, n. 1, p. 165-171, 2007.

SERRA, A. P. et al. Influência do glifosato na eficiência nutricional do nitrogênio, manganês, ferro, cobre e zinco em soja resistente ao glifosato. Ci. Rural, v. 41, n. 1, p. 77-84, 2011.

TAIZ, L.; ZEIGER, E. Fisiologia vegetal. 5.ed. Porto Alegre: Artmed, 2013.918 p.

YAMADA, T.; CASTRO, P. R. C. Glifosato, herbicida com singular modo de ação: efeitos secundários e implicações fisiológicas e agronômicas. In: Potafos. 45 p. 2007.

ZABLOTOWICZ, R. M.; REDDY, K. N. Nitrogenase activity, nitrogen content, and yield responses to glyphosate in glyphosate-resistant soybean. Crop Protec., v. 26, n. 3, p. $370-376,2007$.

ZOBIOLE, L. H. S. et al. Glyphosate reduces shoot concentration of mineral nutrients in glyphosate resistant soybeans. Plant Soil, v. 328, n. 1, p. 57-69, 2010.

ZOBIOLE, L. H. S. et al. Prevenção de injúrias causadas por glyphosate em soja rr por meio do uso de aminoácido.

Planta Daninha, v. 29, n. 1, p. 195-205, 2011. 